\title{
A REDIVISĀO TERRITORIAL DO BRASIL E O PODER CONSTITUINTE
}

\author{
SANSÃO JOSÉ LOUREIRO \\ (Auxiliar de Ensino de Direito Constituicional.)
}

1. A presente pesquisa faz parte de uma monografia (quase que totalmente inédita) sôbre a modificação da base geográfica de Estado-membro em nossa Federação e no Direito Constitucional Comparado.

Representa trabalho, cuja realização foi possível graças ao material encontrado na Biblioteca Pública do Paraná e na Biblioteca da Faculdade.

Pretendendo refletir o pensamento dominante entre os autores de nossas Constituições sôbre a redivisão territorial do País - não discutimos a natureza dos vários Podêres Constituintes - evitamos propositadamente o resumo das opiniões, preferindo as citações diretas, porque a natureza do capítulo, por mais enfadonha que resulte a sua leitura, permite esta liberdade.

Um artigo anterior, (Revista da Faculdade de Direito da Universidade Federal do Paraná - 1969), serve de introdução ao assunto que ora enfrentamos em mais um aspecto.

\section{Constiłuição de $\mathbf{2 5}$ de março de $\mathbf{1 8 2 4}$.}

A Constituição Imperial de 1824 previa a hipótese da subdivisão das Províncias, em seu artigo $2 .^{\circ}$, ao estatuir que 0 território do Brasil estava "dividido em províncias na forma em que atualmente se acha, as quais poderão ser subdivididas como pedir o bem do Estado".

Dissertando sôbre o tema, afirmou PIMENTA BUENO que "a divisão do Império em províncias, qual existia ao tempo em que foi promulgada nossa lei fundamental, assim como a atual, não é nem devia ser de ordem constitucional; não são Estados distintos, ou federados, sim circunscrições territoriais, unidades locais, ou parciais, de 
uma só e mesma unidade geral. São centros de vida, de ordem e de ação administrativa, partes integrantes do Império, como a Constituição expressamente reconhece; podem pois ser subdivididas segundo exigir o bem do Estado.

O importante princípio de homogeneidade ou unidade nacio. nal, que é o laço o mais robusto da fôrça e indivisibilidade do Império, muito lucrará com uma boa divisão de províncias. Não é possível negar que uma divisão proporcıonal exerce muita influência a respeito; a razão o demonstra, e mais de um fato o confirma.

Por isso mesmo que o Império é um e único, que êle não é dividido em províncias senão no sentido e fim de distribuir convenientemente os órgãos da administração, de modo que em tôda a extensão do país haja centros adequados e próximos para o serviço, e bem-ser dos respectivos habitantes, por isso mesmo cumpre ser conseqüente. Assim exige a justiça, para que não haja desigualdade de proteção, assim demanda a política, para que não haja influências desproporcionais, nem zelos, ciúmes, ódios ou perigos; que rompam um justo e previdente equilíbrio".

Para concluir, linhas adiante:

"Cremos ainda assim que a divisão ałual é muito defeituosa e que pode ser desde já muito melhorada. (Grifamos.) Os homens políticos não devem olvidar que um bom sistema a respeito desviará no futuro e sem constrangimento tôda idéia de ambições federais, já outrora suscitados. Os departamentos em França não excedem à área de 360 léguas quadradas, os condados na Inglaterra têm área ainda muito menor". (Direiło Público Brasileiro e Análise da Constituição do Império, Ed. Min. da Justiça, Rio, 1958, p. 22.)

\section{Constituição de 24 de fevereiro de 1891.}

Proclamada a República, em 1889, o Govêrno Provisório e a Assembléia Constituinte trataram desde logo do assunto.

Assim, pelos decretos n. ${ }^{\circ} 510$, de 22 de junho, e 914-A, de 23 de outubro de 1890, ficou estabelecido que: "Art. 3. ${ }^{\circ}$ - Os Estados podem incorporar-se entre si, subdividir-se, ou desmembrar-se, para se anexarem a outros, formando novos Estados, mediante aquiescência das respectivas legislaturas locais, em dois anos sucessivos, e aprovação do Congresso Nacional".

No Projeto da Comissão do Govêrno Provisório o tema veio assim delineado: 
"Art. 3. Qualquer dos Estados atuais poderá incorporar-se a outro Estado com o consentimento dêste e aprovação do Congresso.

Art. 4. Os atuais Estados, e aquêles que resultarem da anexação, conforme o artigo precedente, poderão se subdividir, a todo - tempo, mediante resolução do seu Poder Legislativo e autorização do Congresso.

Parágrafo único. Não será desmembrada porção alguma de um Estado para anexar-se a outro, nem se pode formar Estado nôvo por junção de frações de territórios diferentes, sem proposta e assentimento dos Estados interessados e aprovação do Congresso".

A Comissâo do Congresso Constituinte apresentou a seguinte emenda:

"Art. 4. Os Estados podem incorporar-se entre si, subdividirse ou desmembrar-se, para se anexarem a outros, formando novos Estados, mediante aquiescência das respectivas legislaturas locais, em dois anos sucessivos, e aprovação do Congresso Nacional". (Apud AURELINO LEAL, Teoria e Prática da Constituição Federal Brasileira, Rio, 1925, p. 40.)

Na opinião de AURELINO LEAL "não foi êste assunto objeto de grande cuidado no Congresso Constituinte".

Para AGENOR DE ROURE "não quis a Constituinte de 18901891, como não quis a de 1823, modificar a divisão territorial do Brasil, deixando que continuasse a má distribuição de terras resultante da subdivisão das primeiras capitanias brasileiras. Tôdas as sugestões feitas no sentido de uma alteração nos limites dos atuais vinte Estados do Brasil ficaram sem eco nos dois únicos momentos da nossa vida política em que isso era possível, de modo que a divisão territorial mantém-se hoje tal qual resultou das doações feitas no início da colonização, sem atender-se às condições econômicas e climatéricas das várias zonas do país e às necessidades do transporte: dos Estados, uns têm portos e terras férteis, outros não têm portos embora possuam boas terras; e outros têm portos mas servindo a terras de má produção; êstes são grandes demais e aquêles pequenos demais; vários dêles possuem territórios ricos de minas, de florestas, de águas e de campos, enquanto outros suportam as dificuldades resultantes da aridez das terras, da falta de boas matas, da escassez de água; aqui há fertilidade do solo e pequena população; alí população grande e terras quase estéreis, etc. 
Nunca se cogitou de uma distribuição racional das terras, de uma divisão lógica do território, apesar da louvável inciativa de alguns estadistas e de vários legisladores de 1823 e de 1890-91". (Constituinte Republicana, Rio, 1920, vol. I, p. 181.)

Segundo ROURE, "quem primeiro atacou a questão de um modo positivo e claro foi o sr. AMARO CAVALCANTI (Anais, vol. l, p. 161): "Agora constituídas as províncias em outros tantos Estados, se nos fôsse lícito, nesta matéria, seguir ou atender sòmente aos princípios, fazendo abstração inteira do fato que se impõe inevitável, o meio, verdadeiramente correto seria, aproveitando o ensejo desta reconstrução Pátria, "proceder-se a uma nova divisão do país", como patrimônio comum nacional que o é, distribuindo-se a cada um dos Estados porção igual ou equivalente, quanto possível, de território, de população e mais elementos de riqueza que existem por todo êste vasto continente brasileiro".

Na discussão do projeto, na Constituinte, na sessão de 15 de dezembro de 1890, o deputado mineiro COSTA MACHADO discursou ao apresentar a emenda que posteriormente retirou:

"Devemos distinguir aqui duas hipóteses: a primeira, que os Estados subdividam-se ou desmembrem-se para se anexarem; e a segunda hipótese a de se criar um nôvo Estado. Quanto à primeira, o artigo é admissível, estamos de acôrdo; quanto à segunda, porém, devemos reformar o artigo porque, se o Congresso reconhece como conveniente que dadas certas circunstâncias, deve formar novos Estados, a conseqüência a tirar é a seguinte: a Constituinte deve facilitar a realização dêsse fato. Mas, como realizar-se a criação de novos Estados, tirando para isso território e população de diversos, por consenso próprio, senhores? Os Estados quererão consentir nisso? Por certo que não; ninguém quer perder fôrça nem poder. Logo, se não é impossível será dificílima a criação de novos Estados, com a desmembração de um ou mais Estados. O que convém, por conseguinte? Convém facilitar; mas isso depende de certos requisitos, de certas condições e de um processo especial, o qual deve ser marcado e estabelecido pelo Congresso. . . Demais, êsse artigo é omisso e deficiente, por isso que não cogitou de uma hipótese que pode dar-se; qual é ela? Supondo, meus senhores, que daquí a anos, um território que presentemente é devoluto, tenha bastante população, bastante riqueza, tenha todos os meios, todos os requisitos para formar um Estado; como o Congresso há de fazê-lo em face da Constituição, quando a Constituinte neste artigo não cogita da hipótese? Porque aquí só se trata da subdivisão ou desmembração de Estados para se incorporar, para se criar um nôvo Estado; não se 
trata dessa hipótese, e, por conseguinte, vem a propósito a minha emenda, devolvendo para o Congresso o estabelecer as condições, requisitos e processos a seguir neste caso". (Anais da Constifuinte, vol. I, p. 191; cf. AURELINO LEAL, op. cit, ps. 40-41 e AGENOR DE ROURE, op. cit. p. 187.)

Para o sr. ALMINO AFONSO o artigo era alguma coisa de "ameaçador e aterrador". Explicou seu ponto de vista de que do artigo devesse constar que "cada uma das vinte províncias forma na União um Estado autônomo e indissolúvel" (Anais, vol. III, p. 19.)

O sr. PINHEIRO GUEDES apresentou a seguinte emenda, a seu ver capaz de solucionar o problema da divisão territorial:

"Art. 3. ${ }^{\circ}$. O território nacional será dividido em tantas porções quantas sejam precisas para que cada Estado tenha aproximadamente a mesma extensão e limites naturais.

$\S 10^{\circ}$ - Ficam constituindo territórios, anexos aos Estados, dentro de cujos limites atuais se acharem compreendidas, as zonas pouso ou nada povoadas.

$\S 2 .^{\circ}$ - As zonas que contiverem população regular passarão à categoria de Estados autônomos.

Art. $4 .^{\circ}$ - Cada uma das antigas províncias constitui um Estado, com a mesma denominação atual, sendo, porém, os respectivos territórios delimitados nos têrmos do art. 3. e parágrafos" (Anais, vol. II, p. 468).

Outras sugestões surgiram nos debates travados na primeira Constituinte Republicana, mas o art. $4 .^{\circ}$ ficou com esta redação definitiva:

"Os Estados podem incorporar-se entre si, subdividir-se, ou desmembrar-se, para se anexar a outros, ou formar novos Estados, mediante aquiescência das respectivas Assembléias Legislativas, em duas sessões anuais sucessivas e aprovação do Congresso Nacional". (Constituição de 1891.)

A Reforma Constitucional de 1926 não alterou o art. $4 .^{\circ} \mathrm{da}$ Carta de 1891.

\section{Constituição de 16 de julho de 1934.}

O tema foi bastante debatido na Constituinte de 1933-34 e a forma final, cristalizada no artigo 14 da Constituição de 1934, não constituiu avanço em relação ao texto de 1891 . 
No anteprojeto figurava o seguinte:

"Art. 5. . Os Estados podem incorporar-se entre si, subdividirse ou desmembrar-se para se anexarem a outros ou formarem novos Estados, mediante aquiescência das respectivas Assembléias Legislativas, em duas sessões ordinárias sucessivas e aprovação da Assembléia Nacional“.

Desde logo, a Comissão Constitucional destinada a emitir parecer sôbre o anteprojeto e as emendas do plenário distribuiu a matéria a vários relatores e apresentou substitutivos, dentre êles êste:

Art. 3. ${ }^{\circ}$ A maioria da Comissão adota a emenda 180 (avulso 13), avulso 28 p. 6, que é acorde com a emenda n. 1.626, avulso n. 26, 179, com a seguinte redação:

Art. $3^{\circ}$. Os Estados podem incorporar-se entre si, subdividirse ou desmembrar-se, para se anexarem a outros ou formarem novos Estados, mediante aquiescência das respectivas assembléias legislativas, em duas legislaturas sucessivas, e aprovação por lei federal".

Ficam prejudicadas as emendas números: 65, 114, 181, 237, 680, 739, 778, 1.487, 1.489, 1.591, 1.626 e 1.854. CINCINATO BRAGA - SAMPAIO CORRÊA - PEREIRA LIRA". (Anais da Assembléia Nacional Constituinte, vol. XVII, p. 4.)

Discursou na sessão de 27 de março o Ministro JUAREZ TÁVORA, da Agricultura, abordando o assunto com ênfase (Anais, vol. XI, p. 480), inspirando o sr. PRADO KELLY na apresentação da emenda 1.854. Justificando esta proposição, disse o ilustre jurista fluminense, então constituinte, em explicação pessoal:

"Desmembramento e anexação dos Estados. $\bigcirc$ art. $3 .^{\circ}$ do $1 .^{\circ}$ do Substitutivo era mais ou menos o da Constituição de 91:

"Os Estados podem incorporar-se entre si, subdividir-se ou desmembrar-se, para se anexarem a outros, ou formarem outros Estados, ou territórios mediante aquiescência das Assembléias Legislativas em duas sessões ordinárias sucessivas e aprovação por lei federal".

Êste dispositivo equivale, como disse, em notável oração, ○ Ministro JUAREZ TÁVORA, ao seguinte:

"Não é permitido, constitucionalmente a qualquer dos atuais Estados modificar suas fronteiras.

Parágrafo único: Ressalva-se, entretanto, o direito aos mais for- 
tes, de irem, aos poucos, invadindo os mais fracos, e depois, pelo critério do uti possidetis, legalizarem essa usurpação".

Para obviar êsse mal, e de olhos volvidos às verdadeiras necessidades nacionais, e no desconsôlo de não levar a obra vigente de redivisão territorial do Brasil - oferecemos a emenda n. 1.854, justificada pelas palavras daquele Ministro, em sessão de 27 de març๐:

"Art. 3. - Podem os Estados incorporar-se entre si, subdividir-se ou desmembrar-se para se anexarem a outros ou formarem novos Estados ou territórios.

$\S 1 .^{\circ}$ - A incorporação entre si de dois ou mais Estados para formarem um único, será feita mediante aprovação por maioria absoluta de votos, em uma sessão ordinária das respectivas Assembléias Legislativas, e ratificação do Conselho Federal.

$\S 2 .^{\circ}$ - O desmembramento de parte de um ou mais Estados para anexar-se a outros ou constituir-se em nôvo Estado obedecerá às seguintes condições:

a) representação dos municípios interessados, por meio das maiorias de seus Conselhos Municipais ao Conselho Federal;

b) manifestação da vontade da respectiva população por meio de plebiscito, a que presidirão autoridades federais;

c) homologação, pelo Conselho Federal, da vontade expressa pela maioria;

$\S 3 .^{\circ}$ - O desmembramento de parte do território de um Estado para anexar-se a outro só será permitido quando vise aumentar a área de um Estado menor, em detrimento de outro maior.

$\S 4 .^{\circ}$ - O desmembramento de partes de um só ou mais Estados para constituir-se em nôvo Estado só se verificará: $\mathrm{km}^{2}$;

a) se formarem as mesmas partes uma área mínima de 40.000

b) se essa área fôr povoada, pelo menos, por 300.000 habitantes;

c) se acusar uma arrecadação total mínima de 20.000 contos de réis.

$\S 5 .^{\circ}-$ Em qualquer dos casos previstos nos $\S \S 3 .^{\circ}$ e $4 .^{\circ}$, as partes desmembradas assumirão a responsabilidade de uma parte 
dos compromissos financeiros (dívida externa e interna) do Estado de que se desmembrarem, proporcional às rendas estaduais nelas arrecadadas, além da indenização devida por melhoramentos excepcionais que hajam recebido por conta do mesmo Estado.

$\S 6 .^{\circ}$ - O desmembramento de parte de um Estado, em qualquer caso só se poderá dar:

a) quando a parte restante do Estado seccionado reunir condições de existência autônoma equivalente às do $\S 4 .^{\circ}$;

b) ou quando não possa constituir Estado autônomo, pela deficiência de população e de renda, possua extensão territorial que permita a criação de incorporar-se a outro Estado".

Aí estão, em resumo, o princípio da autodeterminação, o direito de representação e plebiscito, e a remoção dos obstáculos tradicionalmente opostos à celeridade do processo legislativo". (Anais, vol. $X V I$, p. 326.)

Ainda sôbre o assunto fêz uso da palavra o deputado CLEMENTINO LISBOA para dizer: "Pesa-me, Sr. Presidente, não poder admitir a hipótese figurada, há poucos dias desta tribuna, pelo meu nobre amigo deputado Raul Fernandes... quando defendendo o sistema do Substitutivo declarava:

"E os Éstados que não se contentarem com êsse sistema de garantias, que equilibra Norte e Sul, ainda têm uma válvula de segurança, ainda não vista por muita gente, na faculdade que se the deu, retirada à última hora na Comissão mas restabelecida por emenda, de qualquer Estado, por maioria qualificada do seu Poder Legislativo impressa com solenidade em duas reuniões sucessivas, passar a território. Cada um dos Estados terá um meio de se fundir administrativamente e judiciàriamente neste todo, que é o Brasil, renunciando à vida de Estado Federado, para se transformar em território regido pelos podêres federais, com autonomia local como província, com vida municipal protegida, mas administrado por autoridades federais e dotado de juízes federais".

A bancada paraense é radicalmente contrária à transformação dos Estados em Territórios: o suicídio não é remédio para coisa alguma" (Anais, vol. XII, p. 384.) PONCE.

Em seu discurso contra o art. $3^{\circ}$, disse o deputado GENEROSO

"Seja como fôr, o art. 3..$^{\circ}$ não deve ser encarado como instrumento adequado para uma remodelação geral na divisão territorial 
dos nossos Estados. Embora com as longas especificações e determinações sugeridas pelo sr. Ministro da Agricultura, a cuja boas intenções e alto espírito rendo as minhas homenagens; embora com essas longas especificações, que dão bem a medida da complexidade do problema e que melhor poderiam ser cuidadosamente previstas em lei ordinária, como, aliás, há tempos, já propugnara o deputado riograndense do Sul, sr. Joaquim Ozório - embora com as sugestões do sr. Ministro da Agricultura, ou outras que viessem retificar ou ampliar - o art. $3 .^{\circ}$ será sempre apenas uma válvula para os casos especiais que venham a surgir e nunca um meio racional, científico, completo, perfeito, para a ambicionada redivisão geral do Brasil". (Anais, vol. XI, p. 576.)

Antes, à p. 569, havia ponderado o ilustre deputado por Mato Grosso: "Eu disse, sr. Presidente, que nós, os matogrossenses, encaramos com o maior respeito, o maior acatamento, todos os vários projetos de redivisão territorial e política do país; que não seríamos mesmo infensos ao estudo de uma redivisão; que poderíamos fraternalmente discuti-la com os nossos compatriotas das outras unidades federativas, desde que os projetos e alvitres de uma nova divisão territorial e política do país partissem de um ponto de vista geral, duma visão de conjunto de todos os Estados da Federação, e, principalmente, que não houvesse, da parte de seus propositores, de forma alguma, idéias subalternas de preservar os Estados politicamente fortes, em detrimento dos Estados politicamente fracos.

Nesta conformidade, srs. Constituintes, a bancada de Mato Grosso, da mesma forma que as do Amazonas, do Pará, de São Paulo e do Paraná, apresentou emenda supressiva do art. 85 do Anteprojeto, que mandava transformar em territórios as zonas fronteiriças do país, fazendo, assim, uma disfarçada, uma lateral redivisão do país, que de modo algum, colimava com os altos objetivos de redivisão geral".

O General J. RAMALHO, na obra Novos Territórios propôs, no seu projeto de Constituição, um artigo (3. ${ }^{\circ}$ ) assim vasado:

"Os Estados podem incorporar-se entre si, subdividir-se ou desmembrar-se para se anexar a outros ou formar novos Estados, mediante autorização legislativa por maioria de votos e em duas legislaturas da Câmara Federal, salvo na atual". (Citado por GENEROSO PONCE.)

Esta foi a emenda do sr. LEVI CARNEIRO ao Substitutivo concernente à matéria que ora tratamos:

"Art. $30^{\circ}$ - Substituo pelo seguinte a parte final: 
Também poderão os Estados subdividir-se, ou desmembrar-se, para se anexarem a outros, ou formarem novos Estados, ou Territórios, pelos votos dos eleitores das regiões interessadas, na forma da lei federal e com a aprovação da Assembléia Nacional". (Anais, vol. X, p. 623.)

Tornou-se, finalmente, dispositivo constitucional, a seguinte redação: "Art. 14. Os Estados podem incorporar-se entre si, subdividir-se ou desmembrar-se, para se anexar a outros ou formar novos Estados, mediante aquiescência das respectivas Assembléias Legislativas, em duas legislaturas sucessivas e aprovação por lei federal".

\section{Constituição de 10 de novembro de 1937}

Constou do art. $5 .^{\circ}$ da Carta outorgada:

"Os Estados podem incorporar-se entre si, subdividir-se ou desmembrar-se para anexar-se a outros, ou formar novos Estados, mediante a aquiescência das respectivas Assembléias Legislativas, em duas sessões anuais consecutivas, e aprovação do Parlamento Nacional.

Parágrafo único: A resolução do Parlamento poderá ser submetida pelo Presidente da República ao plebiscito das populações interessadas". (Note-se o caráter não imperativo do plebiscito.)

Comentando o artigo, disse PONTES DE MIRANDA: "O texto de 1937 não se diferença dos textos de 1891 e 1934, salvo em pormenores. Influxo do que se inscreveu na Constituição dos Estados Unidos da América (Art. IV, secção 3, alínea $1^{a}{ }^{a}$ ) e na Constituição da República Argentina, sem a referência à possível admissão de novos Estados-membros por ato do Congresso, que naquelas se contém. A Constituição de 1891 não previa, sequer, os pressupostos e o modo pelo qual o Território passaria a Estado-membro. Fê-lo, depois, a Constituição de 1934, sem ser seguida pela de 1937". (Comentários à Constituição Federal de 10 de novembro de 1937 - Pongetti - Rio, 1938, vol. I, p. 233.)

Os Legislativos foram fechados durante o período em que vigorou a Carta de 1937. Nenhum Estado-membro foi criado neste lapso de tempo, mas algumas unidades federadas viram diminuídos seus espaços geográficos com a criação de Territórios Federais.

\section{Constituição de 18 de setembro de $\mathbf{1 9 4 6}$}

A matéria em pauta figurou no art. $3 .^{\circ}$ do anteprojeto apresentado à Assembléia Constituinte de 1946, com a seguinte disposição. 
"Os Estados podem incorporar-se entre si, subdividir-se, para se anexar a outros ou formar novos Estados, mediante o voto das respectivas Assembléias Legislativas, em duas legislaturas sucessivas e aprovação do Congresso Nacional". (Anais da Comissão da Consîtuição, Rio, 1948, vol. I, p. 50.)

O sr. GUSTAVO CAPANEMA apresentou êste substitutivo:

"Art. 3.० - Os Estados podem incorporar-se entre si, e subdividir-se para formarem novos Estados ou para se anexarem, no todo ou em parte, a outros Estados, mediante voto das respectivas assembléias legislativas, em duas sessões anuais sucessivas e aprovação do Congresso Nacional" (op. cit. p. 50).

O sr. ALIOMAR BALEEIRO fêz uso da palavra para "observar que no art. $3 .^{\circ}$ do projeto, o processo para a subdivisão e anexação territorial dos Estados está adstrito apenas à consulta às assembléias legislativas respectivas e à aprovação do Poder Legislativo Federal.

Ora, a meu ver, isso não basta, porque interessados não são sòmente os Estados, no seu todo. Há maior intensidade de interêsses nas populações dos municípios, que vão sofrer alterações territoriais que se derem; e, como o Poder Legislativo Estadual nem sempre tem representante nessas zonas fronteiriças, de pouco valor político, parece que seria de tôda a conveniência, sobretudo de elevado sentido político, que nós, no referido art. $3 .^{\circ}$, determinássemos imperiosamente a consulta direta aos municípios. Essa consulta poderia revestir-se de duas formas, ser feita através da manifestação das Câmaras de Vereadores, nos municípios localizados na zona a ser modificada, ou por consulta direta de natureza plebiscitária, aos elementos ali radicados. Das duas, preferiria a segunda. Parece-me que, num caso como êste, a consulta direta aos eleitores, através do plebiscito, despertaria mais vivamente a consciência das populações, fazendo com que sentissem mais de perto, mais fundamente o problema, e, então, teríamos, aí, conhecida a sua vontade no caso concreto.

Nesse sentido tomei a liberdade de pedir a atenção dos Srs. Constituintes para a emenda, mandando acrescentar após a palavra mediante, o seguinte: "consulta plebiscitária aos eleitores do município interessado", de modo que o artigo ficaria assim redigido:

"Os Estados podem incorporar-se entre si, subdividir-se e formar novos Estados, mediante o voto das respectivas Assembléias Legislativas, ou mediante consulta plebiscitária aos eleitores dos municípios interessados e voto das respectivas assembléias legislativas", - in- 
terferindo novos elementos na formação da vontade para essas anexações territoriais" (idem, p. 50).

O sr. CAFÉ FILHO aparteou o orador para notar que "estou, em princípio, de acôrdo com V. Ex. ${ }^{a}$. A emenda de V. Ex. ${ }^{a}$, entretanto, não estabelece critério para a consulta aos municípios. Figuremos a hipótese de incorporação de certa zona de um Estado a outro, compreendendo vários municípios. Haverá oposição em uns municípios e aceitação em outros. Qual seria o critério?"

Ao que respondeu o Sr. BALEEIRO: "Vamos admitir o exemplo de um Estado querendo incorporar a outro - hipótese aliás dificílima - parte de seu território. A minha emenda, incluída na redação atual, teria como consequiência prática que a formação do acôrdo das vontades dependeria de vários elementos.

Seria necessário que as assembléias legislativas do Estado desfalcado e do Estado acrescido estivessem de acôrdo, do mesmo modo que o Congresso Nacional e a maioria dos eleitores dos municípios interessados. Sem a união dessa série de fatôres, a vontade não estaria firmada.

A modificação territorial dos Estados deve ser caso de exceção. Por isso mesmo, deve ser embaraçada, deve ser objeto de reflexão longa, meditada.

É preciso que não seja simples movimento leviano de correntes partidárias que se indisponham com os governos dos Estados. É preciso que haja longa meditação, que se acentuem as razões de ordem econômica, social ou de outra natureza. Os exemplos poderiam ser multiplicados. É preciso contar com os meios de transporte, com os interêsses do plano geral de financiamento, enfim, com mil outros fatôres.

Acredito que V. Ex. ${ }^{a}$ poderá conciliar o seu pensamento com o meu" (idem, p. 51).

O sr. ARGEMIRO FIGUEIREDO não concordou com a emenda do deputado BALEEIRO: "Ao que me parece, data venia, não devia ser aceita a emenda apresentada pelo ilustre deputado que acaba de falar. Estamos, nesta parte, nos referindo às unidades da Federação ou melhor, tratando da organização federal do Brasil. A sugestão apresentada, pôsto que democrata-liberal, fere de certo modo o critério sistemático a que devemos obedecer na elaboração de uma Constituição. Aqui há referência aos Estados, isto é, às unidades da Federação. De certo modo há razão quando se diz que a população tôda do Estado, ou melhor, a população que constitui os núcleos 
municipais, é diretamente interessada nessa transformação, nessa anexação, nessa divisão de Estados. Realmente, assim é. Mas é presumível, Sr. Presidente, que quando se cogita de medida dessa natureza, dêsse alcance, dessa significação política e social, já ○ Estado, através de seus legítimos representantes, que são os que compõem a Assembléia Legislativa do Estado, já estejam bem inteirados dos sentimentos, das aspirações do povo. Nessas condições, os interêsses de caráter puramente municipais, terão reflexo na Assembléia do Estado, que estará constituída quando se tratar de casos dessa natureza. Dêsse modo, e atendendo também ao fato de ser texto tradicional de nossa Constituição liberal-democrata - que não é inovação, que tem sido mantido integral desde a Carta de 91 até os tempos atuais - acho que o artigo deve ser literalmente mantido" (idem, p. 51).

O sr. ATÍLIO VIVACQUA apresentou emenda, esclarecendo que a mesma obedecia ao projeto do Instituto dos Advogados, assim expressa:

"Nenhum Estado poderá desmembrar-se ou anexar-se, em parte ou no todo, a um Estado, ou transformar-se em território federal, senão mediante 0 voto das respectivas Assembléias Legislativas, em duas legislaturas consecutivas e aprovação do Congresso Nacional". A inovação está apenas na parte referente à transformação em território federal (idem, p. 52).

O sr. EDGAR ARRUDA "propunha... que ao artigo em discussão acrescentássemos também, a hipótese do desmembramento, ficando o dispositivo redigido da seguinte maneira: "Os Estados podem incorporar-se entre si, desmembrar-se, subdividir-se, etc." (idem, p. 52).

O sr. PRADO KELLY, depois de algumas considerações sôbre a matéria que se estava discutindo e sôbre o histórico que o assunto comportava, disse: "Há, entretanto, outra emenda, do Representante Aliomar Baleeiro, que propõe se introduza o princípio da consulta plebiscitária. No tocante ao assunto, êste princípio, realmente, tem merecido acolhida no Direito moderno. Devo, referir-me às Constituições posteriores à $\mathrm{Paz}$ de 1919 e, especialmente, à instituição do referendum na Suíça. Tenho, porém, uma dúvida: é que ou se faz consulta plebiscitária, ou, então, se concede o exame da matéria a um órgão representativo. Na emenda BALEEIRO havia diferentes graus. Primeiro - a consulta plebiscitária - segundo a manifestação das Assembléias Legislativas, em duas legislaturas sucessivas. Ora, uma coisa está em competição ou conflito com a outra. 
Ils hurlent de se trouver ensemble. Parece que seria mais fácil se admitisse a seguinte fórmula:

"Os Estados podem incorporar-se entre si, subdividir-se, para se anexar a outro, ou formar nôvo Estado, mediante consulta plebiscitária às populações interessadas, nos têrmos de resolução das respectivas Assembléias Legislativas e aprovação do Congresso Nacional" (idem, p. 53).

O sr. BENEDITO VALADARES pronunciou-se de acôrdo com a emenda do sr. PRADO KELLY. O sr. GUSTAVO CAPANEMA manifestou-se "contrário ao plebiscito na matéria da incorporação e da subdivisão dos Estados. O plebiscito é procedimento muito sumário. Creio que essa matéria, discutida pelas assembléias legislativas, há de ser sempre resolvida mais fácil e mais seguramente" (idem, p. 54).

O sr. CIRILO JUNIOR deu o voto "no sentido de manter o dispositivo como foi redigido pela subcomissão; e assim voto pelas seguintes razões: a modificação introduzida nas fórmulas anteriores, da Constituição de 91 e da Constituição de 1934, no sentido de exigir-se o voto de duas legislaturas e não, apenas, de duas sessões, envolve, a meu ver, o plebiscito. Não se renova o mandato de uma assembléia contra a vontade de um povo, e o povo é representado pelos munícipes. O segundo fundamento do meu voto está na coerência com o dispositivo já aprovado, e assim redigido: "O Brasil, constituído em Estado Federal, com base na divisão de seu território em Estados Federados... (O sr. NEREU RAMOS: Êste dispositivo não foi aprovado)... O preâmbulo consagra que o regime é democrático representativo. Não posso compreender, data venia das opiniões em contrário, como falar-se, com inspiração na Constituição de 37, em plebiscito. São os fundamentos de meu voto" (idem, p. 55).

Também o sr. MILTON CAMPOS explicou que votou "contra a consulta plebiscitária, que, em princípio, me parece de boa cautela, por entender que o cuidado de se exigirem duas legislaturas consecutivas, e não apenas duas sessões, já pressupõe, de modo indireto, mas certa, essa mesma consulta plebiscitária à vontade dos habitantes" (idem, p. 56).

Submetido à votação o artigo $3 .^{\circ}$, na forma por que foi redigido pela Subcomissão, foi aprovada a seguinte redação:

"Os Estados podem incorporar-se entre si, subdividir-se, para se anexar a outros ou formar novos Estados, mediante voto das respectivas Assembléias Legislativas, em duas legisturas sucessivas, e aprovação do Congresso Nacional" (idem, p. 56). 


\section{Historia o Des. JOSÉ DUARTE:}

"O projeto primitivo, oferecido pela Comissão Constitucional, no art. 115, dispôs: "Os Estados podem incorporar-se entre si, subdividirse ou desmembrar-se, para se anexar a outros, ou formar novos Estados, mediante voto das respectivas Assembléias Legislativas, em duas legislaturas sucessivas, e aprovação do Congresso Nacional".

Aprovado, em primeiro turno, ofereceram-lhe diversas emendas, destacando-se a de RAUL PILA, sob n. ${ }^{\circ}$ 2.690-A, assim concebida: "Redija-se da seguinte forma a parte final do art. 115..." mediante voto das respectivas Assembléias Legislativas, plebiscito das populações interessadas, e aprovação do Congresso Nacional".

Assim a justificou seu autor: "Não se compreende que, numa democracia, tais questões sejam resolvidas sem audiência das populações diretamente interessadas. Se há casos capazes de justificar um plebiscito, êste é, certamente, um dêles".

O deputado GETÚliO MOURA propôs, também, um substitutivo, no qual a parte final, mais ou menos, coincide com a indicação de RAUL PILA: "ouvindo-se, prèviamente, as populações interessadas", o que defende: "O que se impõe, antes de mais nada, é - plebiscito, único meio de auscultar a população diretamente interessada na nova modificação territorial. Este aspecto do problema não foi atendido pelo Projeto Constitucional".

E, depois de invocar JOÃO BARBALHO e RUY BARBOSA, prossegue na sustentação: "Instituída a consulta plebiscitária - que é a forma mais direta e segura de apuração da vontade popular - já se não justifica a aprovação pelo Congresso Nacional. Basta a audiência do Senado, que, no regime federativo, representa a União, pela absoluta igualdade das representações estaduais.

Os interêsses dos Estados já foram consultados com o voto das respectivas Assembléias Legislativas. Falta apenas a palavra da União, através do voto do Senado. A intervenção da Câmara dos Deputados nessa matéria é formalidade dispensável e inútil, com a instituição do plebiscito.

A volta do projeto à Subcomissão ofereceu oportunidade para, aí, ser acolhida apenas a emenda ALIOMAR BALEEIRO, com inserção da consulta plebiscitária". (A Constituição Brasileira de 1946, Rio, 1947, Vol. I, p. 229 e 230.)

Constou da Constituição de 18 de setembro de 1946 esta redação, aprovada pelo plenário: 
"Art. 2. - Os Estados podem incorporar-se entre si, subdividirse ou desmembrar-se para se anexarem a outros ou formarem novos Estados, mediante voto das respectivas Assembléias Legislativas, plebiscito das populações diretamente interessadas e aprovação do Congresso Nacional".

\section{Constituição promulgada a 24 de janeiro de 1967.}

O anteprojeto, emanado do Executivo, dizia: "Art. 3. ${ }^{\circ}$ - A lei complementar disporá sôbre a criação de novos Estados e Territórios, assim como a alteração das respectivas áreas".

A emenda do Senador RUI PALMEIRA foi a seguinte:

"Art. 3. ${ }^{\circ}$ - Substitua-se pelos arts. $2 .^{\circ}$ e $3 .^{\circ}$ da atual Constituição. Justificação: Entregar à lei complementar a criação e a alteração das respectivas áreas dos Estados e Territórios é o golpe mais profundo do projeto na autonomia dos Estados e Municípios. Êsse dispositivo visa a facilitar a execução do propósito de um certo grupo não-político, que proclama a necessidade da reforma territorial do País". (Projeto de Constituição de Iniciativa do Presidente da República - Emendas apresentadas - Publicação do Congresso Nacional - Brasília - D.F. - 1967 - p. 152.)

O Senador CATTETE PINHEIRO, foi mais longe com relação a êsse artigo $3 .^{\circ}$. Eis a sua emenda: "Dê-se ao artigo a seguinte redação:

"Art. 3.० - Os Estados podem incorporar-se entre si, subdividirse ou desmembrar-se para se anexarem a outros ou formarem novos Estados mediante decisão das respectivas Assembléias Legislativas, ratificada em plebiscito das populações diretamente interessadas e aprovação do Congresso Nacional, em lei especial a ser votada com o quorum fixado no artigo 52.

Parágrafo único - A criação de Territórios, a sua constituição em Estados, a sua subdivisão em novos Territórios ou a sua reintegração nos Estados de que tenham sido desmembrados, far-se-á mediante lei especial, votada por maioria absoluta dos membros das duas Casas do Congresso, com prévia audiência do Conselho de Segurança Nacional".

Justificação: "A redação do artigo $3 .^{\circ}$ do projeto afigura-se-nos carente de correção, pois, como está, o dispositivo é omisșo e tem um sentido ambíguo.

Realmente, declarando que a criação de novos Estados e Territórios, assim como a alteração das respectivas áreas, sòmente poderia ser feita por lei complementar, o artigo surge com diversos defeitos. 
Em primeiro lugar, olvida-se a hipótese da alteração de áreas dos atuais Estados e Territórios.

Em segundo lugar, a referência à lei complementar parece-nos imprópria, pois lei complementar é a que complementa a Constituição, dando validade a algum de seus princípios, o que não ocorre na espécie.

Afora isso, sabemos que os motivos determinantes da criação de Territórios dizem muito de perto com a segurança do País, razão por que achamos deva ser ouvido, quando do evento, o Conselho de Segurança Nacional.

Finalmente, atendendo ao que pretende o projeto, fixamos para a votação da matéria o quorum estabelecido para a votação de leis complementares..." (idem, p. 239).

O artigo ficou definitivamente redigido nestes têrmos:

"Art. 3. - A criação de novos Estados e Territórios dependerá de lei complementar".

CONCLUSÃO: A orientação dada ao tema da redivisão ou criação de Estado-membro pelo art. 3..$^{\circ}$ da atual Constituição de 1967 e da Emenda 1, pràticamente iguais, tem dado margem ao surgimento de pontos de vista divergentes na doutrina.

Quanto à dependência de lei complementar, as considerações primeiras são em tôrno da natureza dessa nova espécie de lei de nosso processo legislativo. De acôrdo com o antigo art. 53 da Constituição, as "leis complementares serão votadas por maioria absoluta dos membros das duas Casas do Congresso Nacional, observados os demais têrmos da votação das leis ordinárias". A Emenda Constitucional n. ${ }^{\circ} 1$ à Carta de 1967 - em vigor a partir de 30 de outubro de 1969 - estabeleceu no art. 50: "As leis complementares sòmente serão aprovadas, se obtiverem maioria absoluta dos votos dos membros das duas Casas do Congresso Nacional, observados os demais têrmos da votação das leis ordinárias". Ora, como a própria Carta Magna estabelece quais as hipóteses em que essa lei complementar é exigida, somos de opinião de que temos algo de nôvo em nosso processo legislativo, diferente das antigas leis orgânicas, ou mesmo, daquelas que já foram chamadas complementares. (Para as dissertações anteriores à Constituição de 1967, cf. entre outros A.A. DE MELLO FRANCO, As Leis Complementares da Constituição - tese Rio - 1948; VICTOR NUNES LEAL - Leis Complementares da Constituição - Rev. de Dir. Administrativo, n. ${ }^{\circ}$ VII, 1947 e PAULINO JACQUES, Curso de Direito Constitucional, Rio, 1962, p. 140.) Algumas 
partes da Constituição não são auto-executáveis, havendo, portanto, necessidade de complementação legislativa. Mas as leis complementares, mencionadas em caráter exaustivo pela Constituição, em razão da natureza do assunto, demandam um quorum especial para a sua aprovação. Fora dêsses casos, a complementação comum dar-se-á por aprovação de maioria exigida para as leis ordinárias. Isto porque, em nosso parecer, o Constituinte não quis resolver, desde logo, temas controvertidos, deixando ao legislador ordinário a sua eventual solução, subordinada esta apenas a quorum especial (Contra: JOSÉ AFONSO DA SILVA: "Aplicabilidade das Normas Constitucionais").

O exame do artigo $3 .^{\circ}$ demonstra a razão da crítica que lhe foi apresentada, primeiro, nos trabalhos da Constituinte de dezembro de 1966 - janeiro de 1967, e, depois, pela doutrina constitucional brasileira. Uma redação tão simples pode dar margem a várias interpretações. Por exemplo:

- Os Estados-membros atuais terão sempre o mesmo território, sem possibilidade de modificação. Novos Estados ou Territórios, criados por lei complementar, sòmente poderão surgir dos atuais Territórios Federais.

- A lei complementar poderá criar novos Estados e Territórios, sem qualquer obstáculo por parte dos atuais Estados-membros, inexistente a questão do consentimento. Em suma, esta lei poderá fazer a redivisão territorial total do Brasil.

- A lei complementar, por si mesma, não criará Estados ou Territórios. Traçará, apenas, as diretrizes para a posterior criação dessas entidades, estabelecerá o processo constitucional do qual dependerá a criação de novos Estados e Territórios.

- Dispondo do tema, em forma sintética, o Constituinte pretendeu deixar de lado um problema incômodo, certo de que o art. $3 .^{\circ}$ permaneceria letra morta.

No caso concreto, após a lei complementar, o Supremo Tribunal Federal seria o árbitro máximo das soluções apresentadas, ficando, assim, a solução final fora da alçada política.

grande comentarista das Constituições Brasileiras, PONTES DE MIRANDA, define seu pensamento no seguinte quadro:

“No art. 3. ${ }^{\circ}$ da Constituição de 1967 diz-se que a criação de novos Estados-membros e de Territórios depende de lei complementar. Não se explicitou a) se a lei complementar é federal, ou b) se são pressupostos necessários leis complementares de cada Estado-membro que se incorpora (leis complementares estaduais). Mas a inter- 
pretação que temos de dar é no sentido a), porque o art. $3 .^{\circ}$ está nas Disposições Preliminares e aí não se cogita de qualquer competência de Estados-membros ou de Território...". "Hoje, o Congresso Nacional é que faz a lei complementar federal. Não há aprovação pelo Congresso Nacional, porque não se aprova lei. A incorporação ou desmembramento de áreas do Estado ou do Território é que tem de partir das Assembléias Legislativas, em leis complementares, subordinadas à aprovação pelo Congresso Nacional (art. 47, V). A competência pelo Congresso Nacional, em lei complementar, é de exigirse, de lege ferenda e de lege lała, porque, sem ela, poderia dar-se que Estados-membros, facciosos e separatistas, vissem na fusão o primeiro passo para supremacia ou secessão, ou que dualidades partidárias ou de govêrno chegassem a subdivisões como recurso de acôrdo". (Comentários à Constituição de 1967, S. Paulo, 1967, ps. 495-497.)

Outro brilhante constitucionalista brasileiro, Dr. CLÁUDIO PACHECO, opina:

"Mas hoje, em face do artigo $3 .^{\circ}$ da nova Constituição, que permite a criação de novos Estados por lei complementar, cabe uma correção, no sentido de se reconhecer que agora a supressão ou incorporação de Estados, sempre excluída a mutilação sem deixar condição nenhuma de subsistência, pode ser feita, pela via unilateral e compulsória da mesma lei complementar". (Revista de Ciência Política, Vol. I, n. ${ }^{\circ} 3$, setembro de 1967, p. 91).

O Poder Legislativo tem-se mostrado interessado na questão. Tanto no Senado - projeto VASCONCELOS TORRES, de 18 de maio de 1967 - quanto na Câmara dos Deputados - Projeto TEÓFILO PIRES, Projeto FLORIANO RUBIN, Programa do Bloco Parlamentar pela Redivisão Territorial do Brasil em Novos Estados - temos exemplo disso.

O mesmo acontece com o Poder Executivo, através dos estudos do Conselho de Segurança Nacional e de comissões nomeadas para equacionar o problema e apresentar soluções.

Louvável, sempre, a disposição de nossos Constituintes, de inserir nas Constituições artigos sôbre a redivisão territorial do país. Não se sabe quando o art. $30^{\circ}$ da atual Constituição se tornará realidade. Para os pessimistas, entretanto, trazemos à colação o dispositivo que, em várias Constituições, previa a mudança da Capital da República para o Planalto Central. De repente, surgiu Brasília.

Algum estadista saberá demonstrar, na prática, a sabedoria da redivisão territorial do Brasil. 